\begin{tabular}{|c|c|c|}
\hline & Int.J.Curr.Microbiol.App.Sci (2017) 6(8): 75-89 & \\
\hline & $\begin{array}{l}\text { International Journal of Current Microbiology and Applied Sciences } \\
\text { ISSN: 2319-7706 Volume } 6 \text { Number } 8 \text { (2017) pp. } 75-89 \\
\text { Journal homepage: http://www.ijcmas.com }\end{array}$ & $\begin{array}{l}30 \\
3\end{array}$ \\
\hline $\begin{array}{l}\text { EXCELLENT } \\
\text { PUBLISHERS }\end{array}$ & & wwww.ijemas.com \\
\hline
\end{tabular}

Original Research Article https://doi.org/10.20546/ijcmas.2017.608.011

\title{
Assessment of Metabolic Potential and Insilico Analysis of Enzymes Involved in Inducing Air Pollution Tolerance in Some Angiosperm Plants
}

\author{
Anamika Tripathi ${ }^{1}$, Akhil Gupta ${ }^{1 *}$, Apoorv Tiwari ${ }^{2,3}$ and Anand Pathak ${ }^{4}$ \\ ${ }^{1}$ Pollution Ecology Research Laboratory, Department of Botany, Hindu College Moradabad, \\ University of Rohilkhand, 244001, India \\ ${ }^{2}$ Sam Higginbottom University of Agriculture, Technology and Sciences (SHUATS), \\ Allahabad, 211007, India \\ ${ }^{3}$ Department of Molecular Biology and Genetic Engineering, G.B. Pant University of Agriculture \\ and Technology, Pantnagar, Uttarakhand, 263145, India \\ ${ }^{4}$ Department of Soil Science, G.B. Pant University of Agriculture and Technology, Pantnagar, \\ Uttarakhand 263145, India \\ *Corresponding author
}

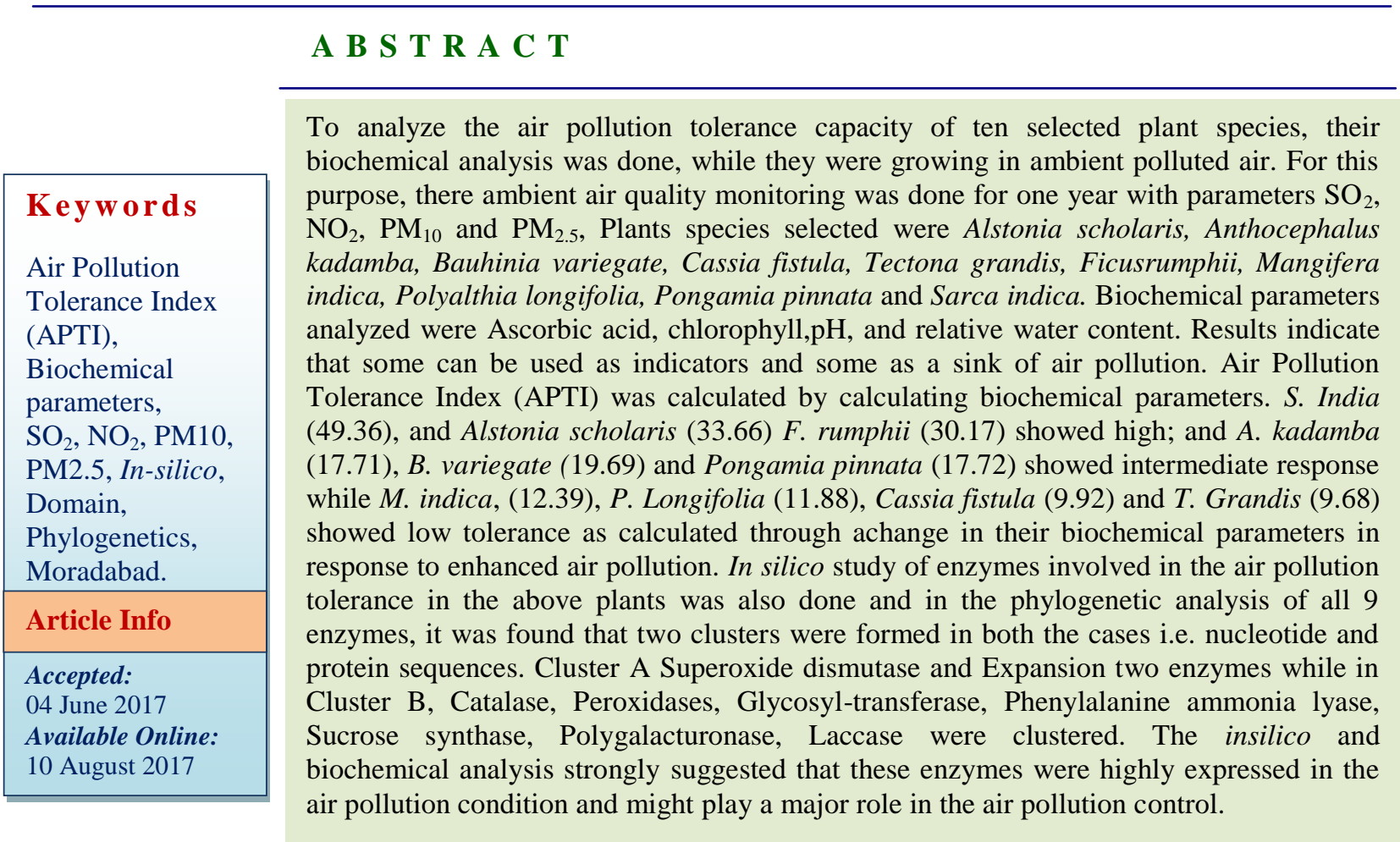

\section{Introduction}

Plants can effectively be used as indicators and pollutant scavengers. Cultivation of trees can serve to be an effective and economical device for the abatement of air pollution. Planting of certain fast growing trees which are resistant to and can withstand the 
increasing air pollution is significantly useful for the air pollution control [14]. Most plants experience physiological changes before exhibiting visible damage to leaves when exposed to air pollutants [18-19]. Pollutants can cause leaf injury, stomatal damage, premature senescence, and a decrease in photosynthetic activities, disturb membrane permeability and reduce growth and yield in sensitive plant species [36]. Certain air pollutants have been reported to reduce chlorophyll content $[14-15,36]$ while others increase it [1].

Vegetation is an effective indicator of the overall impact of air pollution and the effect observed is a time-averaged result that is more reliable than the one obtained from the direct determination of the pollutants in the air over a short period. [28-30]. A large number of trees and shrubs have been identified as dust filters to check the rising urban dust pollution level. Plants provide an enormous leaf area for impingement, absorption, and accumulation of air pollutants to reduce the pollution level in the air environment [6] with various extents for different species [19, 34]. The use of plants as bio indicators of air pollution has long been established because these are the initial acceptors of air pollutants due to having scavenging property for many air pollutants [3]. Plants show varying degree of sensitivity and tolerance to air pollution stress. Chlorophyll content [7]; ascorbic acid content [13]; leaf $\mathrm{pH}$ [17-18] and relative water content have been used in the evaluation of the impact of air pollution on plants. Although, it was observed that separate parameters gave conflicting result for a particular plant [11-12]. Air pollution tolerance index based on the four aforementioned parameters has been used to identify tolerance levels of plant species [4-5, $32,38]$. Some researchers have ranked the different plant species in orderof tolerance to air pollution based on Air pollution tolerance index [23-25, 29, 32].

Different Studies showed that some enzymes of the roadside plants are directly or partially involved in the development of tolerance against air pollution. The activity of plant enzymes including peroxidase, catalase, and ascorbate peroxidase was investigated using spectrophotometric methods. A higher level of peroxidase and catalase enzymes were measured in both plant samples collected from the polluted area [2].

In the present study, we aim to evaluate air pollution tolerance of 10 plant species growing in the vicinity of Moradabad city, by using the Air Pollution Tolerance Index (APTI) method. For this purpose, we did ambient air quality monitoring in Budh Bazar of Moradabad for one year (Sep 2014 -Aug $2015)$ with parameters $\mathrm{SO}_{2}, \mathrm{NO}_{2}, \mathrm{PM}_{10}$ and $\mathrm{PM}_{2.5}$. After gathering the data of the ambient air pollution we analyzed the biochemical parameters of 10 plant species growing in the same region and control site (Shahpura).

\section{Materials and Methods}

\section{Respirable suspended particulate matter $\left(\mathbf{P M}_{10}\right)$}

RSPM samples were collected with the help of Respirable Dust Samplers APM-460 NL (Envirotech, New Delhi) at arate of two samples per week on Whatman glass fiber filter paper - GF-A for $24 \mathrm{hrs}$ (three shift i.e. $8 \mathrm{hrs}$.) with air flow rate of $1-1.5 \mathrm{~m} 3 / \mathrm{min}$. The difference in initial and final weight of the filter paper gave the total quantity of RSPM collected over the 24 hours period. The values of RSPM were reported in $\mu \mathrm{gm}-3$. Calculation of mass concentration of RSPM $\mathrm{RSPM} \mu \mathrm{g} / \mathrm{mW} 2 \mathrm{~W} 110 \mathrm{~V}$ Where, W1=Initial weight of filter paper, W2= Final weight of filter paper $\mathrm{V}=$ Volume of air 
$A=\mathrm{hr} *$ min. $*$ Avg, of manometer reading

\section{Particulate matter 2.5}

Gravimetric method is also used for measuring the mass concentration of $\mathrm{PM}_{2.5}$. The instrument employed is Fine Particulate Sampler (FPS) (Envirotech, New Delhi, Model: APM-550). The operating flow rate for the machine is $1 \mathrm{~m} 3 \mathrm{~h}-1( \pm 5 \%)$, which separates particulates with a larger diameter. The NRPM fraction $(>10 \mu \mathrm{m})$ is separated on the inlet surface of the machine. The particle fraction of $10-2.5 \mu \mathrm{m}$ diameter is separated at surface of glass fiber filter (Whatman GF/A $37 \mathrm{~mm}$ dia) wetted with silicon oil. The $\mathrm{PM}_{2.5}$ fraction escaping is collected on a teflon membrane filter (Whatman of $47 \mathrm{~mm} \mathrm{dia)}$. Dividing the difference between initial and final weights of the teflon membrane filter by the total volume of air sampled gives the mass concentration for $\mathrm{PM}_{2.5}$.

Calculation of mass concentration of PM2.5 $\left(\mu \mathrm{g} / \mathrm{m}^{\mathrm{a}}\right)=\frac{\mathrm{W} 2-\mathrm{W} 1 \cdot 10^{\mathrm{G}}}{\mathrm{V}}$

Where, W1=Initial weight of filter paper, $\mathrm{W} 2=$ Final weight of filter paper, $\mathrm{V}=$ Volume of air

\section{Sampling and analysis of gaseous pollutants}

\section{Sulphur dioxide}

Colorimetric method is used for gaseous sampling. The instrument employed for gaseous sampling is APM-411 fitted and run simultaneously with APM-460 NL RDS. The impingers of $35 \mathrm{ml}$ capacity were filled with $20 \mathrm{ml}$ absorbing reagents, i.e. Potassium tetra chloromercurate $\left(\mathrm{Na}_{2} \mathrm{HgCl}_{4}, \mathrm{TCM}\right)$ exposed $\mathrm{SO}_{2}$ gas in the four hours. Air is sucked through the absorbing reagents in the impingers at a flow rate of $1 \mathrm{~L} \mathrm{~m}^{-1}$. The reagents after reacting with the corresponding gas and converted into the Sulfitomercurate complex. Samples were brought in the laboratory and maintained the loss by additional absorbing reagent and adjusted the volume to $10 \mathrm{ml}$. Added $1 \mathrm{ml}$ Sulphamic acid, $2 \mathrm{ml}$ Pararosaniline hydrochloride, and $2 \mathrm{ml}$ Formaldehyde and wait for 30 minutes for color development then analyzed colorimetrically. $\mathrm{SO}_{2}$ was analyzed employing the modified West-Gaeke method (1956) on a spectrophotometer at a wavelength of $560 \mathrm{~nm}$. Chemicals (Merck, GR-Grade) along with deionized water were used for the preparation of all the reagents and the blanks. Sulphurdioxide concentration in the sample was determined from calibration curve and calculated by the formula- $\mathrm{SO}_{2} \mu \mathrm{g} / \mathrm{m}$ O.D.F. 1000 .

$\mathrm{SO}_{2}\left(\mu \mathrm{g} / \mathrm{m}^{3}\right)=\frac{\mathrm{OD} * \mathrm{~F} * 1000}{\mathrm{~V}}$

$\mathrm{OD}=$ Optical density displayed by spectrophotometer

$\mathrm{F}=$ Factor calculated by calibration graph

$\mathrm{V}=\quad$ Volume
$(A=$ hours $*$ minuts $*$ avg, of rotameter reading $)$

\section{Nitrogen dioxide}

$\mathrm{NO}_{2}$ was analyzed employing the modified Jacob-Hochheiser method. The colourimetric method is also used for $\mathrm{NO}_{2}$ sampling.

The instrument employed for gaseous sampling is APM-411 fitted and run simultaneously with APM-460 NL RDS. The impingers of $35 \mathrm{ml}$ capacity were filled $20 \mathrm{ml}$ with appropriate absorbing reagents, sodium hydroxide with sodium arsenite for NO2. Air is sucked through the absorbing reagents in the impingers at a flow rate of $1 \mathrm{~L} \mathrm{~m}-1$. The reagents after reacting with the correspondinggassesa reanalysed colorimetrically in the laboratory. The nitrite 
ion produced during sampling is reacted with $1 \mathrm{ml}$ Phosphoric acid, $10 \mathrm{ml}$ Sulphanilamide and $1 \mathrm{ml} \mathrm{n}^{-1} \quad$ Naphthyl ethylene diaminedihydrochloride (NEDA) and left for color development. Finally readings were taken on the spectrophotometer at a wavelength of $540 \mathrm{~nm}$. Chemicals (Merck, GR-Grade) along with deionized water were used for preparation of all the reagents and the blanks. Nitrogen dioxide concentration in the sample was determined from calibration curve and calculated by the formula-

$\mathrm{NO}_{2}\left(\mu \mathrm{g} / \mathrm{m}^{3}\right)=\frac{\mathrm{OD} * \mathrm{~F} * 1000}{\mathrm{~V}}$

$\mathrm{OD}=$ Optical density displayed by spectrophotometer

$\mathrm{F}=$ Factor calculated by calibration graph

$\mathrm{V}=\quad$ Volume of Air

( $A=$ hours $*$ minuts $*$ avg, of rotameter reading)

\section{Ascorbic acid content}

For ascorbic acid determination, 500mg of the fresh sample was homogenized with $20 \mathrm{ml}$ of ice-cold extracting solution $(500 \mathrm{mg}$ Oxalic acid and $0.75 \mathrm{mg}$ of EDTA, dissolved in $100 \mathrm{ml}$ distilled water). The homogenate was centrifuged at $6000 \times \mathrm{g}$ for 15 minutes. The supernatant was used for determination of ascorbic acid by using the Keller method [16]. To $1 \mathrm{ml}$ of supernatant, $5 \mathrm{ml}$ of $20 \mu \mathrm{g} / \mathrm{ml}$ of 2,6dichlorophenol (DCPIP) solution was added with constant shaking and O.D. of the pink coloursolution was taken at $520 \mathrm{~nm}$ wavelength (Es) on a UV-VIS spectrophotometer (Systronics Model 119, India). The pink color of the solution was bleached by adding one drop of $1 \%$ aqueous ascorbic acid and O.D. of the turbid solution was taken of the same wavelength (Es). The blank solution was prepared by adding $1 \mathrm{ml}$ distilled water, $548 \mathrm{ml}$ of DCPIP solution, and O.D. was taken at the same wavelength
(Es). A calibration curve was prepared by using varying concentrations of ascorbic acid solution. Ascorbic acid content was calculated by using the following formula:

Ascorbic acid $(\mathrm{mg} / \mathrm{g})=(\mathrm{Eo}-\mathrm{Es}-\mathrm{Et}) * \mathrm{~F}$

Where Eo, Es and Et are the optical densities of blank, plant samples and samples with one drop of $1 \%$ ascorbic acid which was added to it. Calibration curve for ascorbic acid was prepared using chemically pure ascorbic acid.

\section{Relative leaf water content (RWC)}

Fresh weight was obtained by weighing the fresh leaf samples collected from different sites. The leaves were then immersed in water overnight, blotted dry and then weighted to get turgid weight. Then leaves were dried overnight in an oven at $70^{\circ} \mathrm{C}$ and reweighed to obtain the dry weight. According to the method described by Liu and Ding (2008), relative leaf water content was determined and calculated with the formula:

Leaf RWC $(\%)=((F W-D W) /(T W-D W)) \times 100$

Where: $\mathrm{FW}=$ fresh weight; $\mathrm{TW}=$ turgid weight; DW = dry weight

\section{Leaf extract pH}

Five grams of the fresh leaves were homogenized in $10 \mathrm{ml}$ deionized water. This was then filtered and the $\mathrm{pH}$ of leaf extracted determined after calibrating $\mathrm{pH}$ meter with a buffer solution of $\mathrm{pH} 4$ and 9 [1].

\section{APTI determination}

The air pollution tolerance index (APTI) was computed by using the equation and formula [32].

$\mathrm{APTI}=[\mathrm{AA}(\mathrm{TCh}+\mathrm{pH})+\mathrm{RWC}] \div 10$ 
Where: $\mathrm{AA}=$ Ascorbic acid content $(\mathrm{mg} / \mathrm{g})$, $\mathrm{TCh}=$ total chlorophyll $(\mathrm{mg} / \mathrm{g}), \mathrm{pH}=\mathrm{pH}$ of leaf extract, and $\mathrm{RWC}=$ relative water content of leaf $(\%)$.

\section{In silico analysis of enzymes}

In silico analysis of 9 different enzymes involved in air pollution tolerance was performed through different bioinformatics approaches.

\section{Sequence retrieval}

NCBI database was used to retrieve the nucleotide sequence of all enzymes of different plants.

\section{ORF prediction and conserved domain prediction}

ORF finder tool of NCBI was used to predict open reading frame in the nucleotide sequence. The domain is the functional part of sequence and prediction of the domain in sequence provide functional information about the protein. The conserved domain was predicted by the CD-Search tool of NCBI.

\section{Sub cellular localization prediction}

Subcellular localization of different enzymes was predicted using a neural network-based tool (http://www.cbs.dtu.dk/services/Target P/). The location with the highest score is the most likely according to Target $\mathrm{P} 1.1$ tool. The localization of peptide may be chloroplast transit peptide, mitochondrial targeting peptide or a signal peptide.

\section{Phylogenetic analysis}

Multiple sequence alignment and Phylogenetic analysis of all enzymes was done by MEGA V6.0 on both the nucleotide as well as Protein level with the bootstrap value 1000 [33].

\section{Physicochemical analysis}

Prot-Param (http://www.expasy.org/tools/prot param.html) computes various physicochemicalproperties that can be deduced from a protein sequence. The proteins can either bespecified as a SwissProt/TrEMBL accession number or ID, or in the form of a raw sequence. Physicochemical analysis of each was computed using ProtParam tool [9].

\section{Results and Discussion}

The ambient air quality monitoring of one year revealed the results depicted in figures 1 , 2, 3, 4, 5. Gaseous pollutants, as well as particulate matter, was found to be higher than the permissible limits of WHO (40 $\mu \mathrm{g} / \mathrm{m}^{3}$ for PM); USEPA (100 $\mu \mathrm{g} / \mathrm{m}^{3}$ for PM) and NAAQMS $\left(140 \mu \mathrm{g} / \mathrm{m}^{3}\right)$. Temperature variation shows that for many months it is far more than the normal limits.

Monthwise variation of gaseous pollutants shows that it is exceeding the permissible limits of WHO, USEPA, NAAQS. Relative humidity and particulate matter also exceeded the permissible limits.

Humidity showed many spells of variation in a year than any other gaseous pollutant and particulate matter. Ten Plant species growing in such a state of climatic conditions and pollutants were selected and were analyzed for biochemical parameters.

The analysis of biochemical parameters showed a marked variation among species. Chlorophyll content ranged between $2.87 \mathrm{mg} / \mathrm{g}$ to $16.84 \mathrm{mg} / \mathrm{g}$ among all species. In F. Rumphii and $S$. indica the chlorophyll content was found highest. The ascorbic acid was found in the range of $1.43 \mathrm{mg} / \mathrm{g}$ to 16.56 $\mathrm{mg} / \mathrm{g}$ among the plant species taken for study. The $\mathrm{pH}$ ranged 4.87 to 11.2 among all 
species. High pH may increase the efficacy of conversion from hexose sugar to ascorbic acid, while the low leaf extract $\mathrm{pH}$ showed the shows good correlationwith sensitivity to air pollution.

Relative water content varied from $62 \%$ to $85 \%$ indifferent plants species. High RWC helps the plants to maintain its physiological balance under stress condition such as exposure tp air pollution when the transpiration rates are usually high.

Therefore the plants with high RWC may be tolerant to pollutants under a stressed condition.

Air Pollution Tolerance Index (APTI) has been calculated of 10 plant species growing nearBudhBazarof Moradabad city of western Uttar Pradesh and the data is presented in figure 6. For this purpose, it is essential to evaluate the tolerance level of different plant species to air pollution using changes in four biochemical parameters namely ascorbic acid content, total chlorophyll, relative water content and $\mathrm{pH}$ value (Table 1).

The above biochemical parameters that are analyzed for calculation of APTI values are extremely important to understand the resistivity and susceptibility of different plant species [26-27, 31].

The ascorbic acid content was maximum $16.56 \mathrm{mg} / \mathrm{g}$ in theSarcaindicaat study site. The results indicate that the low ascorbic acid concentration range from 2.64 to $16.6 \mathrm{mg} / \mathrm{g}$ at the residential site and high at traffic and industrial sites that range from 4.65 to 15 mg/g (Figs. 5 and 6). The present study reveals that total chlorophyll content in all theurban plants varies with the pollution status of thearea. The higher pollution level in the form ofindustrial and urban pollution lowers the chlorophyllcontent. Total chlorophyll was found maximum $16.9 \mathrm{mg} / \mathrm{g}$ and minimum $4.3 \mathrm{mg} / \mathrm{g}$ in Ficus rumphii at an industrial site and residential site respectively.

The present study shows that in the case of Anthocephalus kadamba, F. rumphii, and Polyalthia longifolia, the total chlorophyll content in the experimental sample with respect to the control was found high (Fig. 6).

The results of the present investigation indicate that there exist a strong and positive correlation $(\mathrm{r}=0.91)$ between $\mathrm{pH}$ of leaf extract and APTI values in experimental and control samples (Fig. 7). Correlation between $\mathrm{pH}$ and Ascorbic Acid was found positively significant $(r=0.85)$ and hence the leaf extract $\mathrm{pH}$ on the higher side give tolerance to plants against pollution (Table 2) [2]. Chl and APTI also showed strong positive correlation (0.81).

Relative water content is associated with protoplasmic permeability in cells causes loss of water and dissolved nutrients, resulting in early senescence of leaves [22]. The results of the present investigation suggest a strong and positive correlation $(\mathrm{r}=0.57)$ between $\%$ relative water content and APTI values of control and experimental samples of different plant species (Table 2).

The results of the present study reveal that the ten different plant species at polluted site and control site shows considerable variation in their susceptibility to air pollution and they responded differently at each site to air pollutants (Table 1).

The plants with high and low APTI can serve as tolerant, moderately tolerant and sensitive species respectively. Tree species falling under Tolerant species (APTI > 30), moderately tolerant $(17<\mathrm{APTI}>30)$ and sensitive Species (APTI < 17) are presented in table 1 . 
Table.1 Biochemical parameters of selected species studied at polluted site (BB), and control site (SP)

\begin{tabular}{|c|c|c|c|c|c|}
\hline Name of plant species & SITE & Chl(mg/g) & $\begin{array}{l}\text { Ascorbic acid } \\
(\mathrm{mg} / \mathrm{g})\end{array}$ & $\mathbf{p H}$ & RWC (\%) \\
\hline \multirow[t]{2}{*}{ Alstonia scholaris } & $\mathrm{BB}$ & 13.31 & 9.15 & 8.10 & 79.45 \\
\hline & SP & 12.19 & 8.5 & 7.23 & 71.23 \\
\hline \multirow[t]{2}{*}{ Anthocephalus cadamba } & $\mathrm{BB}$ & 6.13 & 5.73 & 5.93 & 86. \\
\hline & SP & 10.53 & 5.28 & 8.24 & 78 \\
\hline \multirow[t]{2}{*}{ Bauhinia variegata } & BB & 12.77 & 6.9 & 6.2 & 64 \\
\hline & SP & 11.87 & 4.3 & 5.8 & 62 \\
\hline \multirow[t]{2}{*}{ Cassia fistula } & $\mathrm{BB}$ & 6.87 & 2.6 & 5.7 & 67 \\
\hline & SP & 5.62 & 2.2 & 6.9 & 64 \\
\hline \multirow[t]{2}{*}{ Tectona Grandis } & BB & 5.7 & 2.3 & 6.9 & 81 \\
\hline & SP & 4.9 & 1.4 & 9 & 84 \\
\hline \multirow[t]{2}{*}{ Ficus Rumphii } & $\mathrm{BB}$ & 14.2 & 9.3 & 11.5 & 85 \\
\hline & SP & 16.8 & 8.5 & 5.7 & 69 \\
\hline \multirow[t]{2}{*}{ Mangifera. Indica } & BB & 4.8 & 3.7 & 4.8 & 77 \\
\hline & $\mathrm{SP}$ & 3.3 & 1.9 & 5.7 & 68 \\
\hline \multirow[t]{2}{*}{ Polyalthia longofolia } & BB & 3.1 & 4.9 & 4.7 & 68 \\
\hline & SP & 2.80 & 4.2 & 7.1 & 58 \\
\hline \multirow[t]{2}{*}{ Pongamia pinnata } & $\mathrm{BB}$ & 9.3 & 6.6 & 6.9 & 84 \\
\hline & SP & 7 & 3.9 & 9.3 & 77 \\
\hline \multirow[t]{2}{*}{ Sarca indica } & $\mathrm{BB}$ & 13.5 & 16.6 & 8 & 81 \\
\hline & SP & 15.4 & 14.5 & 7.5 & 82 \\
\hline
\end{tabular}

Table.2 Functional domain analysis of enzymes involved in inducing Tolerance against air pollution

\begin{tabular}{|c|c|c|c|}
\hline S. No. & Enzyme & Domain & Position \\
\hline \multirow[t]{2}{*}{1} & \multirow[t]{2}{*}{ Catalase } & $\begin{array}{l}\text { Catalase -like heme-binding proteins and protein } \\
\text { domain }\end{array}$ & $1-48$ \\
\hline & & $\begin{array}{l}\text { Catalase -like heme-binding proteins and protein } \\
\text { domain }\end{array}$ & $335-655$ \\
\hline 2 & Peroxidase & $\begin{array}{l}\text { Protein Disulfide Oxidoreductases and Other Proteins } \\
\text { with a Thioredoxin fold }\end{array}$ & $1-363$ \\
\hline \multirow[t]{2}{*}{3} & \multirow[t]{2}{*}{ Super oxide dismutase } & $\begin{array}{l}\text { Iron/manganese superoxide dismutases, C-terminal } \\
\text { domain ;superoxide dismutases (SODs) catalyze }\end{array}$ & $52-123$ \\
\hline & & $\begin{array}{l}\text { Iron/manganese superoxide dismutases, C-terminal } \\
\text { domain ;superoxide dismutases (SODs) catalyze }\end{array}$ & $14-49$ \\
\hline \multirow[t]{3}{*}{4} & \multirow[t]{3}{*}{ Expansine } & Rare lipoprotein A (RlpA)-like double-psi beta-barrel & $294-557$ \\
\hline & & $\begin{array}{l}\text { Pollen allergen; This family contains allergens lol PI, } \\
\text { PII and PIII from Loliumperenne. }\end{array}$ & $594-809$ \\
\hline & & Expansine A Provisional & $180-963$ \\
\hline 5 & Glycosyltransferase & Glycosyltransferases catalyze & $25-1383$ \\
\hline 6 & $\begin{array}{l}\text { Phenylalanine ammonia } \\
\text { layese }\end{array}$ & $\begin{array}{l}\text { Class I_like superfamily: contains the lyaseclass I } \\
\text { family, histidine ammonia-lyase and phenylalanine } \\
\text { ammonia-lyase }\end{array}$ & $2-451$ \\
\hline \multirow[t]{2}{*}{7} & \multirow[t]{2}{*}{ Sucrose synthase } & Glycosyltransferases catalyze & $1-345$ \\
\hline & & Glycosyltransferases catalyze & $394-795$ \\
\hline 8 & Polygalacturonase & $\begin{array}{l}\text { Polysaccharide Lyase Family 6; Polysaccharide Lyase } \\
\text { Family } 6 \text { is a family of beta-helical polysaccharide } \\
\text { lyases }\end{array}$ & \\
\hline
\end{tabular}


Table.3 Physiochemical properties of enzymes involved in inducing tolerance against air pollution

\begin{tabular}{|l|c|c|c|c|c|l|}
\hline Enzyme & $\begin{array}{c}\text { Number } \\
\text { of amino } \\
\text { acids }\end{array}$ & $\begin{array}{c}\text { Molecular } \\
\text { weight }\end{array}$ & $\begin{array}{c}\text { Theoretical } \\
\text { pI }\end{array}$ & $\begin{array}{c}\text { Negatively } \\
\text { charged } \\
\text { residues }\end{array}$ & $\begin{array}{c}\text { Positively } \\
\text { charged } \\
\text { residues }\end{array}$ & Chemical Formula \\
\hline Catalase & 108 & 12595.52 & 7.87 & 10 & 11 & $\mathrm{C}_{580} \mathrm{H}_{855} \mathrm{~N}_{153} \mathrm{O}_{150} \mathrm{~S}_{7}$ \\
\hline Peroxidases & 110 & 12313.06 & 7.63 & 12 & 13 & $\mathrm{C}_{558} \mathrm{H}_{861} \mathrm{~N}_{141} \mathrm{O}_{165} \mathrm{~S}_{4}$ \\
\hline Super oxide dismutase & 103 & 12145.32 & 9.96 & 6 & 15 & $\mathrm{C}_{547} \mathrm{H}_{877} \mathrm{~N}_{159} \mathrm{O}_{142} \mathrm{~S}_{6}$ \\
\hline Expansin & 260 & 28333.46 & 9.48 & 11 & 23 & $\mathrm{C}_{1262} \mathrm{H}_{1915} \mathrm{~N}_{355} \mathrm{O}_{352} \mathrm{~S}_{20}$ \\
\hline Glycosyl-transferase & 470 & 52295.21 & 6.05 & 52 & 47 & $\mathrm{C}_{2360} \mathrm{H}_{3725} \mathrm{~N}_{625} \mathrm{O}_{685} \mathrm{~S}_{15}$ \\
\hline $\begin{array}{l}\text { Phenyl amanine } \\
\text { ammonia layese }\end{array}$ & 146 & 15379.47 & 8.79 & 10 & 12 & $\mathrm{C}_{670} \mathrm{H}_{1086} \mathrm{~N}_{194} \mathrm{O}_{210} \mathrm{~S}_{5}$ \\
\hline Sucrose synthase & 234 & 26276.97 & 6.17 & 28 & 25 & $\mathrm{C}_{1178} \mathrm{H}_{1833} \mathrm{~N}_{317} \mathrm{O}_{347} \mathrm{~S}_{9}$ \\
\hline Polygalacturonase & 42 & 4720.38 & 7.95 & 3 & 4 & $\mathrm{C}_{204} \mathrm{H}_{325} \mathrm{~N}_{61} \mathrm{O}_{62} \mathrm{~S}_{3}$ \\
\hline Laccase & 594 & 65525.31 & 6.56 & 47 & 44 & $\mathrm{C}_{2926} \mathrm{H}_{4436} \mathrm{~N}_{808} \mathrm{O}_{878} \mathrm{~S}_{17}$ \\
\hline
\end{tabular}

Table.4 Localization of all enzymes involved in air pollution tolerance

\begin{tabular}{|l|l|l|l|l|l|l|l|}
\hline Name & Len & cTP & mTP & SP & Other & Loc & RC \\
\hline gi_257144752_emb_FN4 & 108 & 0.151 & 0.111 & 0.113 & 0.752 & - & 2 \\
\hline gi_283827716_gb_GU26 & 110 & 0.016 & 0.058 & 0.776 & 0.374 & S & 3 \\
\hline gi_296279986_gb_HM02 & 103 & 0.016 & 0.819 & 0.008 & 0.526 & M & 4 \\
\hline gi_60116607_gb_AY600 & 260 & 0.005 & 0.175 & 0.869 & 0.042 & S & 2 \\
\hline gi_1002152705_gb_KT9 & 470 & 0.177 & 0.055 & 0.047 & 0.381 & - & 4 \\
\hline gi_310697407_gb_HM53 & 146 & 0.191 & 0.051 & 0.008 & 0.904 & - & 2 \\
\hline gi_350601655_gb_JN00 & 234 & 0.118 & 0.098 & 0.137 & 0.864 & - & 2 \\
\hline gi_163637656_gb_EU31 & 42 & 0.053 & 0.76 & 0.062 & 0.258 & M & 3 \\
\hline gi_565995328_gb_KF92 & 594 & 0.026 & 0.117 & 0.733 & 0.098 & S & 2 \\
\hline
\end{tabular}

Fig.1 Average annual value of temperature in Budd bazaar for the year 2015 (Months)

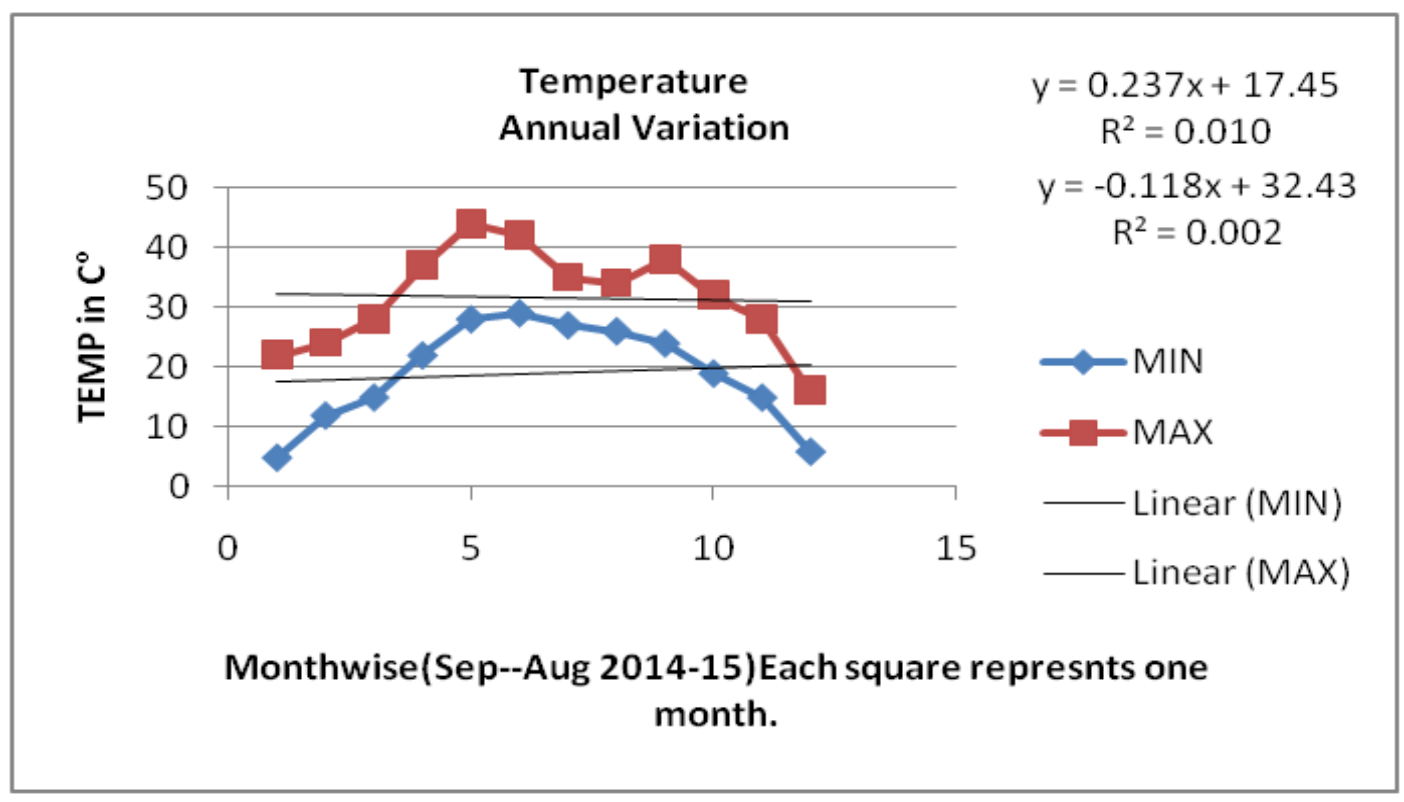


Fig.2 Average annual value of gaseous pollutants in Budd bazaar for the year 2015(Months)

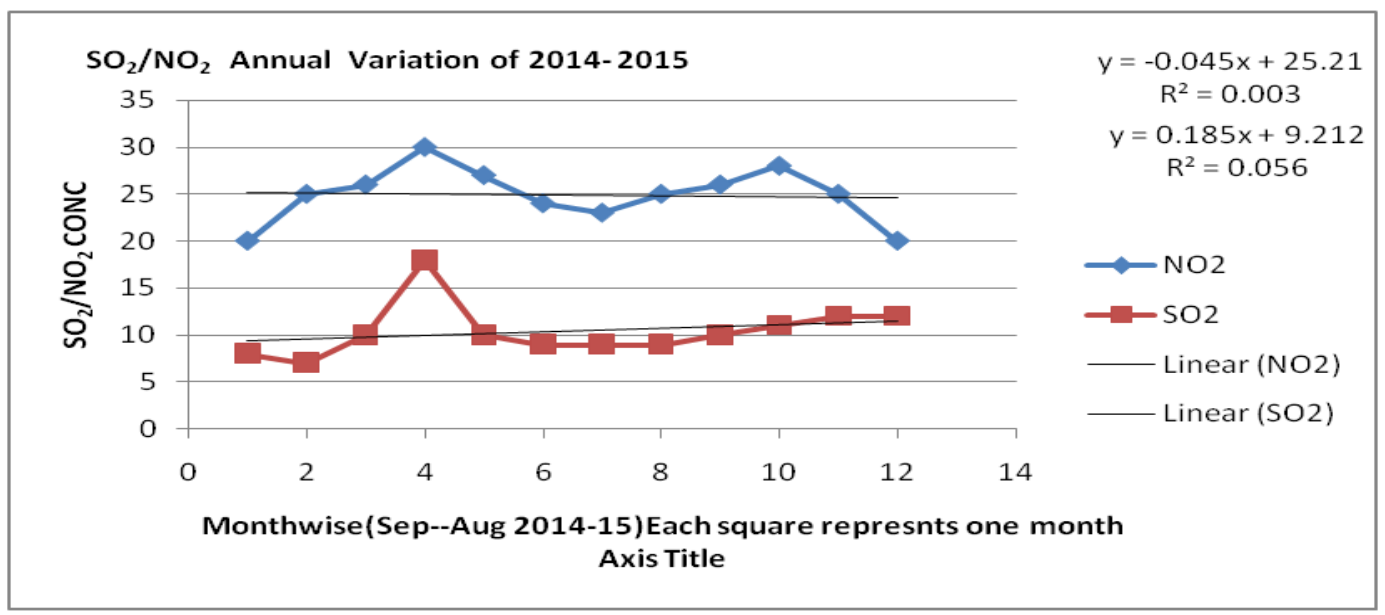

Fig.3 Average annual RH value in Budd bazaar for the year 2015

(Months, Data obtained from meteorological department)

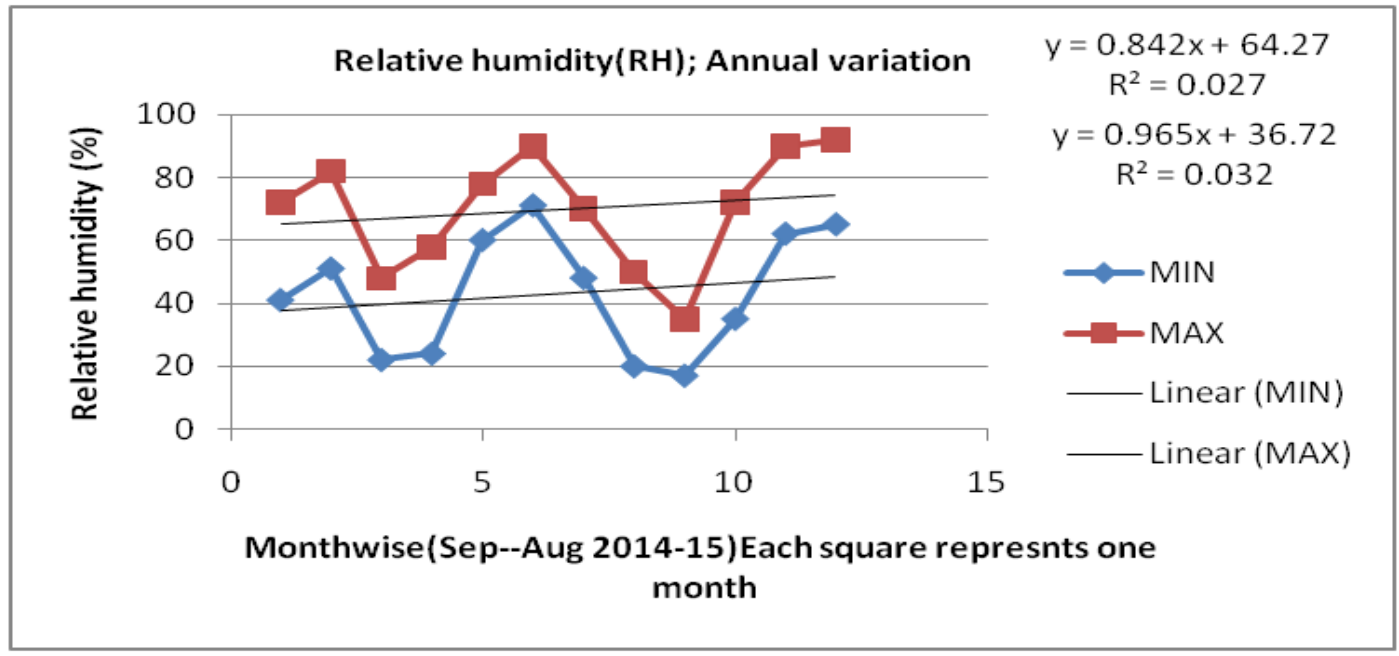

Fig.4 Average annual particulate matter value $\left(\mu \mathrm{g} / \mathrm{m}^{3}\right) \mathrm{n}$ Budh bazar for the year 2015(Months-Sep to Aug)

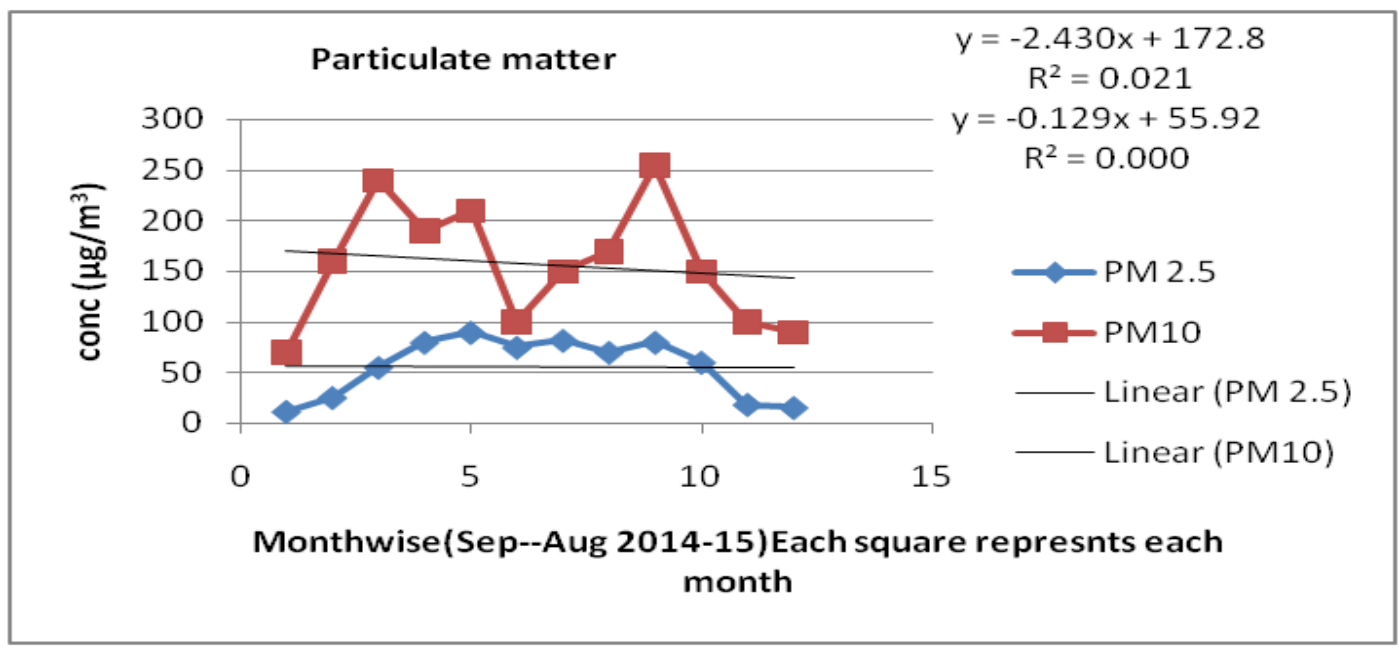


Fig.5 Variation in APTI of different species growing in Budh bazar and control site; Series 1=BB (Budh Bazar). Series 2=Control Site Shapura (SP)

\section{Variation APTI of diffrent plant species}

Series1 - Series 2

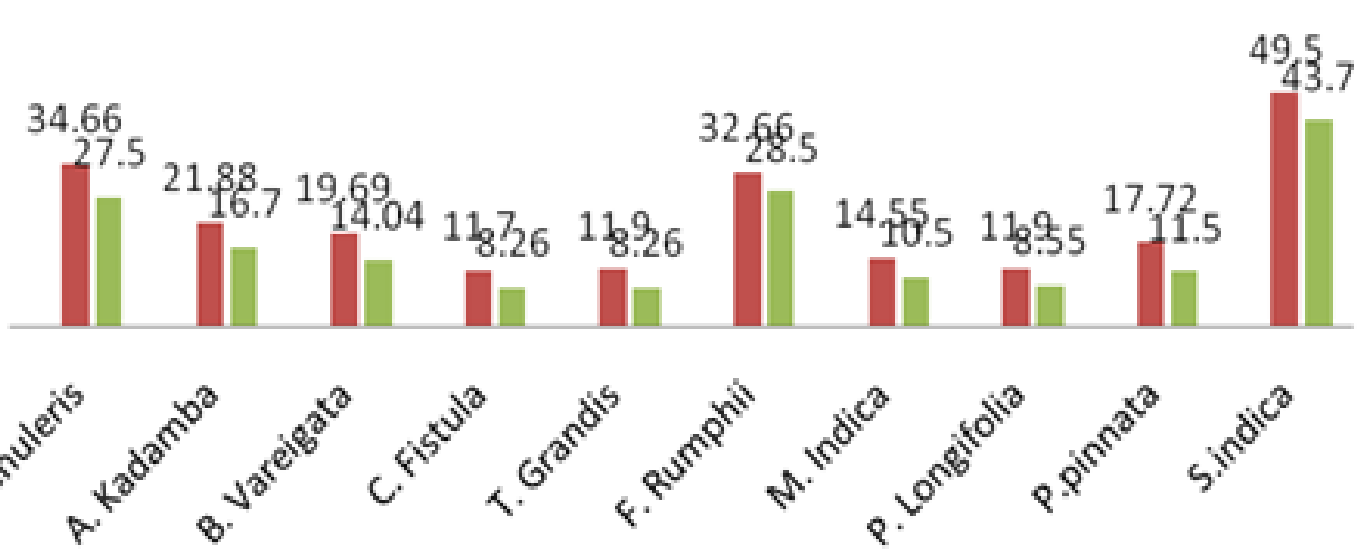

Fig.6 Biochemical parameters of various plants species exposed to enhanced level of air Pollution around Budh bazaar area (Chl and Ascorbic acid mg/g, R.W.C in \%)

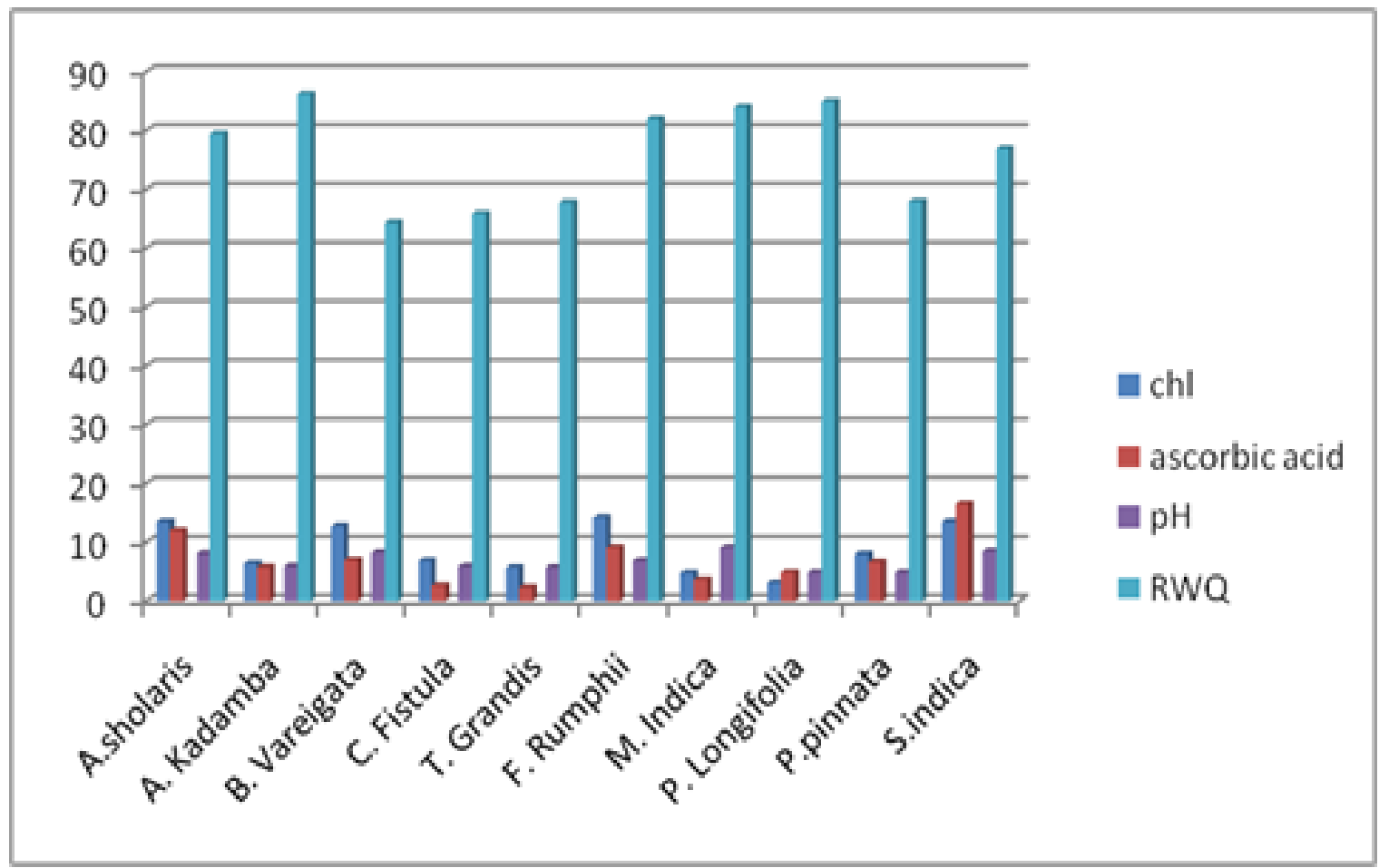


Fig.7 Correlation between biochemical parameters of plants studied in the polluted area (BB). The red color shows the maximum correlation, yellow shows the minimum correlation and other color shows moderate correlation

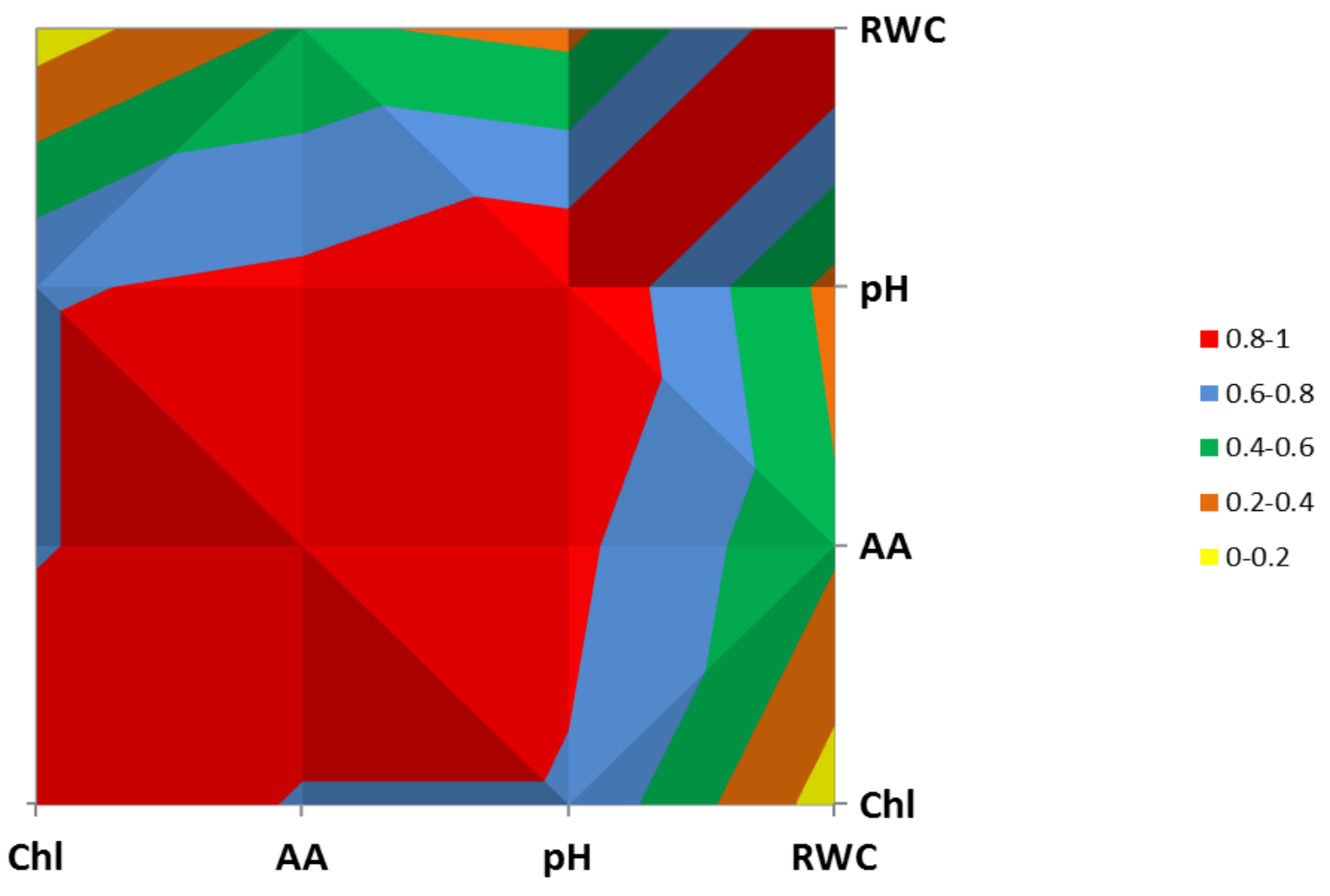

Fig.8A Phylogenetic analysis on the basis of nucleotide sequence of enzymes of different plants Involved in air pollution tolerance

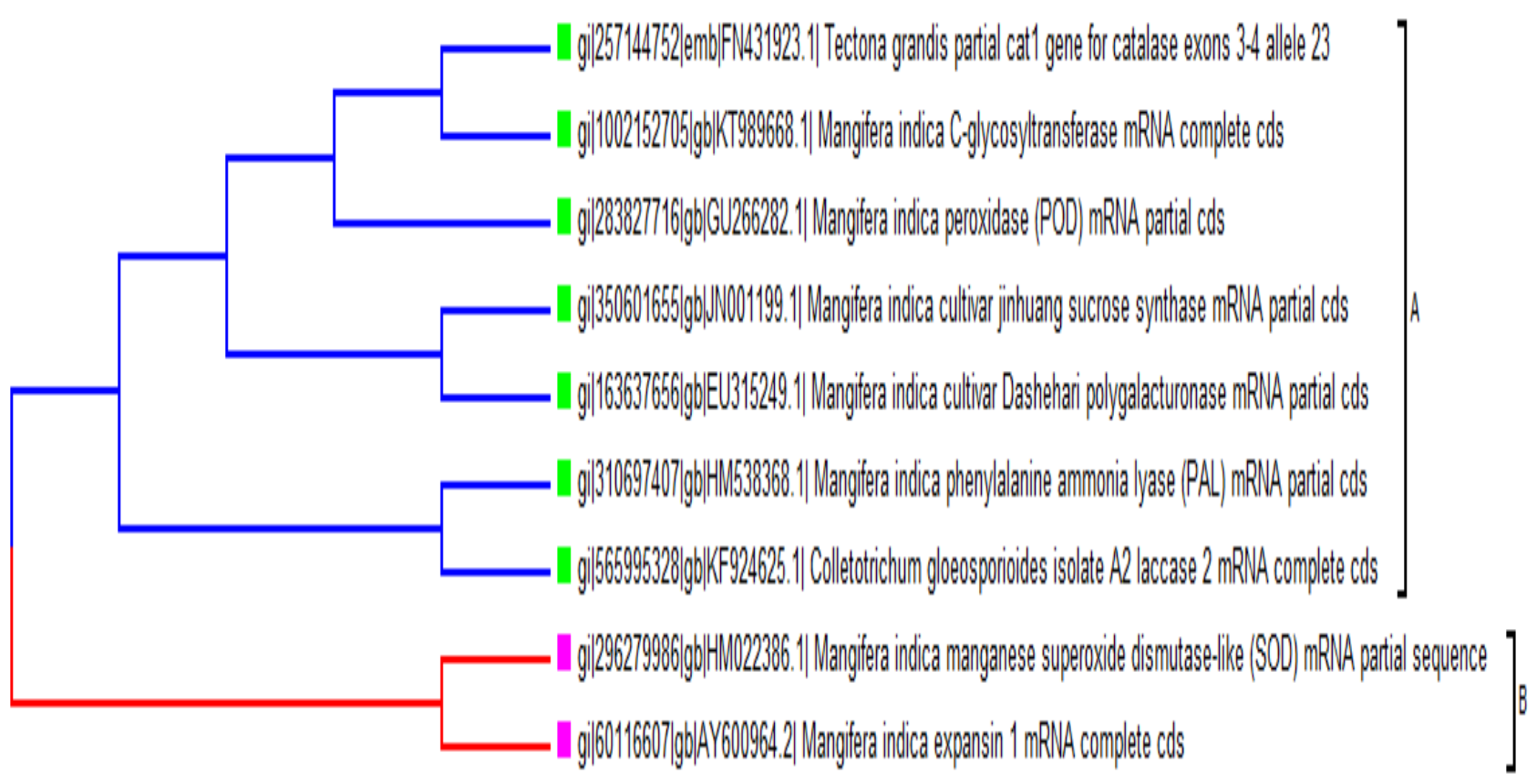


Fig.8B Phylogenetic analysis on the basis of the protein sequence of enzymes of different plants Involved in air pollution tolerance

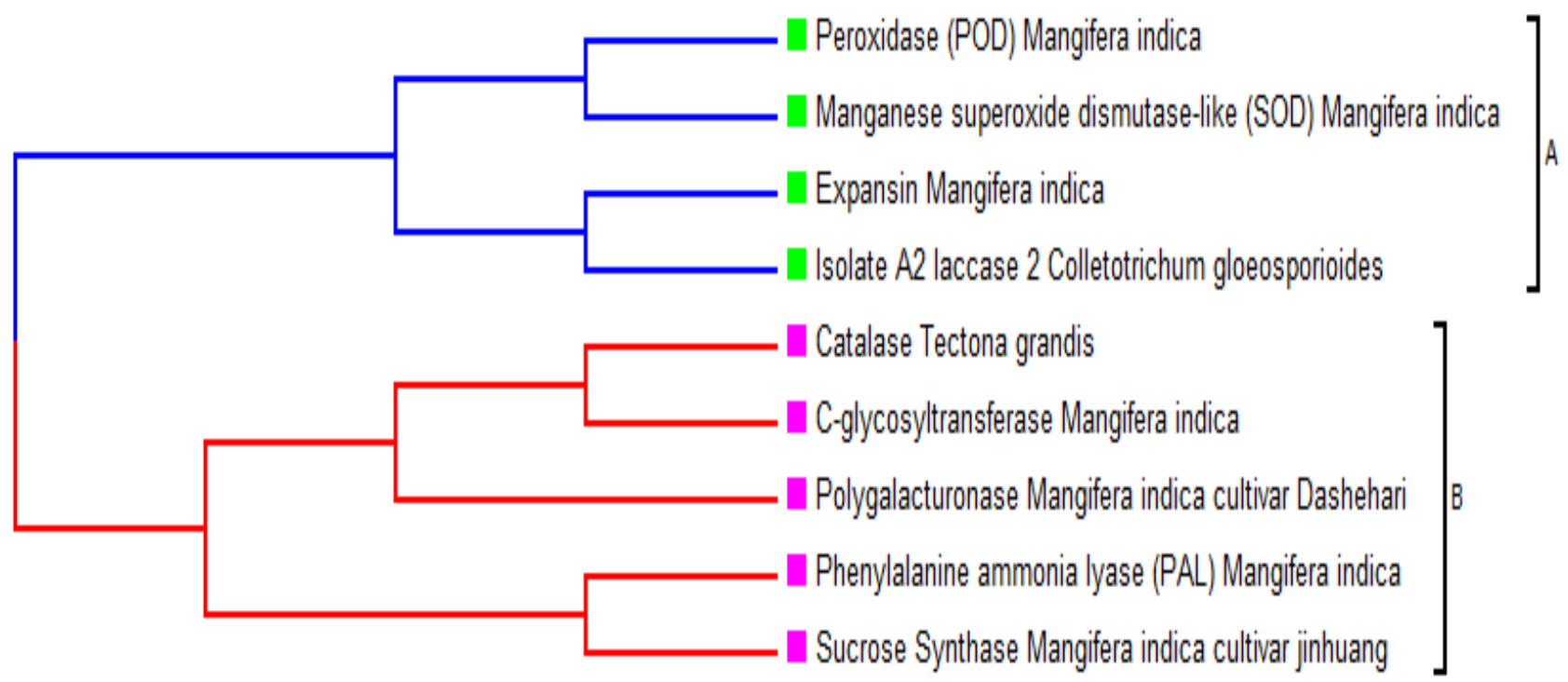

\section{In silico analysis}

Nucleotide Sequence retrieval of all enzymes involved in air pollution tolerance like Catalase, Peroxidase, Superoxide dismutase, expansion, UDP-glucose pyrophosphorylase, glycosyl transferase family, phenylalanine ammonia-lyase (PAL), caffeoyl-CoA 3-Omethyl-transferase (CCoAOMT), Sucrose synthase, polygalacturonase, and Laccase was done by NCBI database [20].

The open reading frame of above enzymes was done by ORF Finder and a different number of the open reading frame was found for each enzyme of different plant species. A conserved domain in the nucleotide sequence was analyzed by CD-Search tool of NCBI and different functional domains was found in the nucleotide sequence of enzymes. Some of them have only one domain and some have more than one. Domain and the position in the nucleotide sequence have been described in detail in the (Table 2) [20, 35, 37]. To find the physicochemical property of each peptide sequence of different enzymes was done by Protparam tool. The nature of protein and number of positive and negative amino acid, isoelectric point, the number of atoms $(\mathrm{C}, \mathrm{N}$, $\mathrm{H}, \mathrm{O})$ was predicted and the detail of all physiochemical enzyme is listed in table 3 [9].

The location with the highest score is the most likely according to Target $\mathrm{P}$, and the relationship between the scores may be an indication of certainty of the prediction. According to the prediction results, three proteins act as the signal peptide and two as mitochondrial targeting peptide and rest of all are located at other places. The detailed description of the localization site prediction was shown in (Table 4) [21].

The phylogenetic analysis described that two clusterswere formed on both the level i.e. nucleotide and protein sequence of enzymes. In Cluster A; Catalase, C-glycosyl transferase, Peroxidase, Sucrose Synthase, Polygalacturonase, Phenylalanine ammonia lyase and Laccase enzymes are clustered while in cluster B Superoxide dismutase and expansineis clustered. In the case of the peptide sequence, multiple sequence 
alignment and phylogenetic analysis were done and it was found that two clusters A and B were formed. In cluster A, peroxidase, superoxide dismutase, expansin and laccase were clustered while in cluster B rest of all enzymes were clustered (Figs. 8A and 8B).

In conclusion, the highest value of APTI was recorded for Sarca indica (49.36) and least value of APTI in T. grandis (9.68).T. Grandis, $C$. fistula, $P$. longifolia fall in sensitive category. Bauhinia variegata was found moderately tolerant to air pollution. Out of ten different species, four were found insensitive categorythus they can be considered as sensitive plant species. They can serve as an indicator of air pollution. The most obvious damage was reported in the leaves i.e. chlorophyll content. The major damages caused by air pollutants to plants include chlorosis, necrosis, and epinasty. In present study $S$. indica, $F$. Rumphii and $A$. Scholaris showed remarkable tolerance to ambient air pollution. Since there biochemical and physiological response augments their tolerance. Therefore these species can be planted in large numbers in air pollution hotspots. The in-silico characterization of enzymes involves in inducing air pollution tolerance to lead us to conclude that there are certain conserved domains which have a different binding site for proteins at different positions and that protein important role in enhancing air pollution tolerance. On the basis of their metabolic potential, enzymes were clustered in two groups. The in silico analysis is an attempt here to understand the functioning of 'enzymes of interest' at the molecular level.

\section{Acknowledgement}

The authors are grateful to the University Grant Commission (UGC); New Delhi for providing financial support for this study.

\section{References}

1. Agbair P.O. and Esiefarienrhe E. 2009. Air Pollution Tolerance Indices (APTI) of some plants around Otorogun gas plants in Delta state, Nigeria. J ApplSci Environ Manage. (13):11-14

2. Al-Muwayhi M.A.R. 2012. Effect of ascorbic acid on lipid and protein contents of Phaseoulsvulgaris L grown at gaseous polluted areas in Riyadh city, Saudi Arabia New Horizons Sci Techno., (3):65-70

3. Ataabadi M., Hoodaji M., Najafi P. 2011. Biomonitoring of some heavy metal contaminations from a steel plant by above ground plants tissue. African $J$ Biotec. 10 (20): 4127-4132,

4. Dwivedi A.K., Tripathi B.D., Shashi 2008. Effect of Ambient air sulphur dioxide on sulphate accumulation in Plants. J Environ Biol. 29(3): 377-379.

5. Dwivedi A.K., and Tripathi B.D. 2007. Pollution tolerance and distribution pattern of plants in surrounding area of coal-fired industries. J Environ Biol. 28(2): 257-263

6. Escobedo F.L., Wagner J.E., Nowak D.J. 2008. Analyzing the cost effectiveness of Santiago, Cile's policy of using urban forests to improve air quality. J Environ Manag. 86: 148-157

7. Flowers M. Krzemińska, H. Bem, H. Górecka 2006. Trace Metals Concentration in Size-Fractioned Urban Air Particulate Matter in Łódź, Poland. I. Seasonal and Site Fluctuations Polish J. Environ. Stud. 15(5): 759-767

8. Flowers M.D., Fiscus E.L., Burkey K.O. 2007. Photosynthesis, chlorophyll flourescene and yield of snap bean (Phaseolus vulgaris L) genotypes differing in sensitivity to Ozone. Environ Exp Bot., 61(2): 190-198

9. Garg V.K., Avashthi H, Tiwari A., et al., (2016). MFPPI - Multi FASTA 
Prot-Param Interface. Bioinformation, 12(2): 74-77.

10. Gasteiger E., Hoogland C., Gattiker A., Duvaud S., Wilkins M.R., Appel R.D., Bairoch A.; 2005. Protein Identification and Analysis Tools on the ExPASy Server; (In) John M. Walker (ed): The Proteomics Protocols Handbook, Humana Press. Pp. 571-607.

11. Han X. and Naeher L. P. 2006. A review of traffic-related air pollution exposure assessment studies in the developing world. Environ Int., 32: 106120.

12. Han Y., Wang Q.Y., Han G.X. 1995. The analysis about SOD activities in leaves and plants and resistance classification of them. Journal of Liaoning University (Natural Science Edition) 22(1): 71-74

13. Hoque M.A., Banu M.N.A., Oluma E. 2007. Exogenous proline and glycinebetaine increase $\mathrm{NaCl}$ - induced Ascorbate-glythione cycle enzyme activities and praline XI improves salt tolerance more than glycinebetaine in tobacco bright yellow-2 suspensioncultural cells. Journal of plant physiology 164(11): 1457-1468

14. Joshi P.C., Swami A. 2009. Air pollution induced changes in the photosynthetic pigments of selected plant species. J. Environ. Biol. 30:295298.

15. Joshi P.C., Swami A., 2007. Physiological response of some tree species under roadside automobile pollution stress around city of Haridwar, India. Environmentalist 27: 365-374

16. Keller,T. and Schwager,H. 1977. Air pollution and ascorbic acid. Eur. J. Forest Pathol. 7: 338-350.

17. Klumpp A., et. al., 2009.Air borne trace metal element pollution in 11 European cities assessed by exposer of standardised ryegrass culture. Atmos. Environ. 43 (2):329-339.

18. Klumpp G., Furlan C.M., Domingos M. 2000. Response Of stress indicators and growth parameters of Tibouchina pulchra Cogn exposed to air and soil pollution near the industrial complex of Cubatao, Brazil. Science Total Environ 246(1): 79-91

19. Liu Yan-Ju, Ding H. 2008. Variation of air pollution tolerance index of plants near a steel factory: implications for landscape-plant species selection for industrial areas. WSEAS transactions on Environment and Development. 4(1): 24-32

20. NCBI Resource Coordinators. 2013. Database resources of the National Center for Biotechnology Information. Nucleic Acids Research, 41(Database issue), D8-D20. http://doi.org/10.1093/ nar/gks1189.

21. Nielsen H., Brunak S., and Heijne G.V. 2000. Predicting subcellular localization of proteins based on their N-terminal amino acid sequence of Emanuelsson. $J$. Mol. Biol., 300: 1005-1016.

22. Nithamathi C. P. and Indira V. 2005. Impact of air pollution on Ceasalpiniasepiaria L. in Tuticorin City., Indian J Environ Ecoplanning, 10 (1), 449-452.

23. Pal R., Atul Kumar, Akhil Gupta, Mahima and Tripathi A. 2014b. Source identification and distribution of toxic metals in respirable dust $\left(\mathrm{PM}_{10}\right)$ in Brasscity of India. Glob. J. Human Soci. Sci. 14 (1):1-12

24. Pal R., Mahima, Gupta A., Singh C., Tripathi A., Singh R. B. 2013. The Effects of Fireworks on Ambient Air and Possible Impact on Cardiac Health, During Deepawali Festival in North India. World Heart Journal. 5 (1): 2132. 
25. Pal, R., Mahima, Gupta A., and Tripathi, A.(2014). Assessment of heavy metals in suspended particulate matter in Moradabad, India. Journal of Environmental Biology 35(2):357-61 .

26. Prasad D. and Choudhury 1992.Effects of air pollution.In: Misra, S.G. (Ed), Environmental pollution Air, Environmental Pollution and Hazards Series. Venus Publishing House, New Delhi. pp. 58-60.

27. Prasad M.N.V., Hagemeyer J. 1999. Heavy metal stress in plants - from molecules to ecosystems. Springer, Heidelberg.

28. Randhi U. D. and Reddy M. A. 2012. Evaluation of Tolerant plant species in Urban Environment: A case study from Hyderabad, India. Uni J Environ Res Techno. 2(4):300304

29. Raza S.H. and Murthy M.S.R. 1988.Air Pollution Tolerance index of certain plants of Nacharam Industrial Area, Hyderabed. Indian J Bot. 11(1): 91-95.

30. Seyyednejad S.M., Nikneja M. Koochak H. 2011. A Review of some Different Effects of air pollution on plants. Res $J$ EnvSci (4): 302-309.

31. Singare P. U., Talpade M. S. 2013. Physiological Responses of Some Plant Species as a Bio-Indicator of Roadside Automobile Pollution Stress Using the Air Pollution Tolerance Index Approach. Int J Plant Res. 3(2): 9-16 DOI: 10.5923/j.plant.20130302.01

32. Singh S.K. and Rao D.N. 1983. Evaluation of plants for their tolerance to air pollution. In ProcSympOn Air pollution control IIT Delhi. Pp. 218-224

33. Tamura K, Stecher G, Peterson D, Filipski A, and Kumar S. 2013. MEGA6: Molecular Evolutionary Genetics Analysis Version 6.0. Molecular Biology and Evolution 30: 2725-2729.

34. ThambavaniSarala D. and Kumar S. 2011. The monthly charges of chloroplast Pigment content in selected Plant Species exposed to cement dust pollution. J Res Biol. 8: 660-666.

35. Tiwari A., et al., (2016). Insights using the molecular model of Lipoxygenase from Finger millet Eleusinecoracana (L.). Bioinformation 12(3): 156-164.

36. Tiwari S., Agrawal M., Marshall F.M. 2006. Evaluation of ambient air pollution impact on carrot plants at a sub urban site using open top Chambers. Environ. Monit. Assess. 119: 15-30.

37. Yadav N., Tiwari A., Garg V.K. (2016). Multiple Sequence Alignment of Model Plants Using Bioinformatics Approach. International Journal of Agriculture Innovations and Research. 4(5), 23191473.

38. Yan-Jul., and Hui D. 2008. Variation in air pollution tolerance index of plant near a steel factory; implication for landscape- plant species selection for industrial areas. Environ. Dev. 1(4): 2430 .

\section{How to cite this article:}

Anamika Tripathi, Akhil Gupta, Apoorv Tiwari and Anand Pathak. 2017. Assessment of Metabolic Potential and Insilico Analysis of Enzymes Involved in Inducing Air Pollution Tolerance in Some Angiosperm Plants. Int.J.Curr.Microbiol.App.Sci. 6(8): 75-89. doi: https://doi.org/10.20546/ijcmas.2017.608.011 